\title{
Evidence for Hydrogen Abstraction from C1 of Taurine by the High-Spin Fe(IV) Intermediate Detected during Oxygen Activation by Taurine: $\alpha$-Ketoglutarate Dioxygenase (TauD)
}

\author{
John C. Price, Eric W. Barr, Timothy E. Glass, Carsten Krebs, and J. Martin Bollinger, Jr. \\ Department of Biochemistry and Molecular Biology and Department of Chemistry \\ The Pennsylvania State University, University Park, PA 16802
}

\section{$\underline{\text { Supporting Information }}$}

Characterization of synthetic 1-[ $\left[{ }^{1} \mathrm{H}\right]_{2}$-taurine and $1-\left[{ }^{2} \mathrm{H}\right]_{2}$-taurine:

1- $\left[{ }^{1} \mathrm{H}\right]_{2}$-taurine:

${ }^{1} \mathrm{H}$ NMR $\left(22{ }^{\circ} \mathrm{C}, 300 \mathrm{MHz}, \mathrm{D}_{2} 0\right): 3.05$ ppm triplet $(2 \mathrm{H}), 3.3 \mathrm{ppm}$ triplet $(2 \mathrm{H})$.

${ }^{13} \mathrm{C}$ NMR $\left(22{ }^{\circ} \mathrm{C}, 75 \mathrm{MHz}, \mathrm{D}_{2} 0\right): 47.7 \mathrm{ppm}$ singlet, $35.7 \mathrm{ppm}$ singlet.

$m / z=124\left([\mathrm{M}-\mathrm{H}]^{-}, 100 \%\right)$.

$1-\left[{ }^{2} \mathrm{H}\right]_{2}$-taurine:

${ }^{1} \mathrm{H}$ NMR $\left(22{ }^{\circ} \mathrm{C}, 300 \mathrm{MHz}, \mathrm{D}_{2} 0\right): 3.27 \mathrm{ppm}$ singlet.

${ }^{13} \mathrm{C}$ NMR $\left(22{ }^{\circ} \mathrm{C}, 75 \mathrm{MHz}, \mathrm{D}_{2} 0\right): 47.3 \mathrm{ppm}$ quintet $(J=20.3 \mathrm{~Hz}), 35.5 \mathrm{ppm}$ singlet. $\mathrm{m} / \mathrm{z}=126\left([\mathrm{M}-\mathrm{H}]^{-}, 100 \%\right)$.

Deuterium incorporation has been determined to be $98 \%$ by simulation of the relative intensities of the peaks between $m / z=124$ and $m / z=128$ in the mass spectrum.

Method for measurement of steady state $\alpha$-ketoglutarate decarboxylation

${ }^{14} \mathrm{CO}_{2}$ was measured by a procedure modified from that described by Jones et al. ${ }^{10}$ In a $5{ }^{\circ} \mathrm{C}$ cold room, $10 \mu \mathrm{L}$ of enzyme mix ( $7 \mu \mathrm{M}$ TauD , $0.5 \mathrm{mM} \mathrm{Fe}(\mathrm{II})$, and $10 \mathrm{mM}$ imidazole, $\mathrm{pH}$ 6.9), pre-loaded with iron $30 \mathrm{~s}$ prior to initiating the reaction, was added to $40 \mu \mathrm{L}$ of assay mix $\left(6.34 \mathrm{mM}\left[1-{ }^{14} \mathrm{C}\right]-\alpha \mathrm{KG}\right.$ $(0.788 \mathrm{Ci} / \mathrm{mole}), 6.25 \mathrm{mM}{ }^{1} \mathrm{H}$-taurine or ${ }^{2} \mathrm{H}$-taurine, $50 \mathrm{mM}$ Tris $\left.\bullet \mathrm{HCl}, \mathrm{pH} 7.6\right)$. The reaction was allowed to proceed in the cap of a $1.5 \mathrm{~mL}$ microfuge tube that was placed at the bottom of a hermetically sealed $20 \mathrm{~mL}$ glass scintillation vial, which also contained a flat-bottomed, cylindrical, 0.8 $\mathrm{cm} \times 3.5 \mathrm{~cm}$ tube. The tube contained the $\mathrm{CO}_{2}$ trap $(\mathrm{a} 1.5 \times 1.5 \mathrm{~cm}$ piece of filter paper that had been soaked in $2 \mathrm{M} \mathrm{NaOH}$ and blotted partially dry). After a reaction time of between 10 and $80 \mathrm{~s}$, the reaction was quenched and $\mathrm{CO}_{2}$ liberated by the addition of $1 \mathrm{~mL} 2 \mathrm{M} \mathrm{HCl}$ through the rubber septum cap sealing the top of the scintillation vial. The liberated $\mathrm{CO}_{2}$ was allowed to bind to the filter paper at room temperature for a period of about $90 \mathrm{~min}$. After equilibration, the septum was removed from the vial, and the filter paper was removed from the flat-bottomed tube. The filter paper was placed into a new uncapped scintillation vial and left to dry overnight at $37^{\circ} \mathrm{C}$. Scintillation fluid was added and the ${ }^{14} \mathrm{CO}_{2}$ counted in a LKB Wallac 1217 Rackbeta liquid scintillation counter. The total counts from the assay mix were measured by placing a known amount of the assay mix directly onto a piece of $\mathrm{NaOH}-$ treated filter paper, which was then dried and counted as above.

Legends for Supporting Scheme and Figures:

Scheme S1: Kinetic mechanism used to simulate the stopped-flow data and the kinetics of the first intermediate determined by Mössbauer. The $\Delta \varepsilon_{318}$ parameters are the differences in the molar absorptivities of the intermediate states at $318 \mathrm{~nm}$ from the corresponding value of the reactant complex.

Figure S1: Kinetic-difference spectrum obtained by subtraction of the spectra of an $\mathrm{O}_{2}$ free control from the experimental time-dependent spectra of the complete reaction. In the experiment, 
a solution of $2 \mathrm{mM}$ TauD, $1.8 \mathrm{mM} \mathrm{Fe}{ }^{2+}, 10 \mathrm{mM} \alpha \mathrm{KG}$ and $10 \mathrm{mM}$ synthetic ${ }^{1} \mathrm{H}$-taurine (A) or ${ }^{2} \mathrm{H}$-taurine (B) in $50 \mathrm{mM}$ Tris buffer ( $\mathrm{pH}$ 7.6) was mixed with a solution of air-saturated buffer in a 2:5 volume ratio. The spectra were recorded $0.028 \mathrm{~s}$ (blue line), $0.21 \mathrm{~s}$ (red line), $2.6 \mathrm{~s}$ (green line), and $10 \mathrm{~s}$ (black line in B only) after mixing.

Figure S2: Mössbauer spectra (recorded at $4.2 \mathrm{~K}$ in a $40-\mathrm{mT}$ magnetic field applied parallel to the $\gamma$ beam) of samples prepared by rapid freezing of the reaction at $5{ }^{\circ} \mathrm{C}$ of a solution of the quaternary $\mathrm{TauD} \bullet \mathrm{Fe}(\mathrm{II}) \bullet \alpha \mathrm{KG} \bullet$ taurine complex with $\mathrm{O}_{2}$-saturated buffer (1:1 volume ratio). The concentrations after mixing were: $2 \mathrm{mM}$ TauD, $1.8 \mathrm{mM} \mathrm{Fe}, 5 \mathrm{mM} \alpha \mathrm{KG}$, and $5 \mathrm{mM}$ taurine. Spectra $\mathbf{A}, \mathbf{B}$, and $\mathbf{C}$ are of samples for which ${ }^{2} \mathrm{H}$-taurine was employed and were quenched $0.084 \mathrm{~ms}, 2.0 \mathrm{~s}$, and $5.0 \mathrm{~s}$, respectively, after mixing. Spectra $\mathbf{D}, \mathbf{E}$, and $\mathbf{F}$ are of samples for which ${ }^{1} \mathrm{H}$-taurine was employed and were quenched $0.021 \mathrm{~s}, 0.084 \mathrm{~s}$, and 0.16 $\mathrm{s}$, respectively, after mixing. The solid lines are theoretical simulations according to the previously reported parameters ${ }^{2}\left(\delta=0.31 \mathrm{~mm} / \mathrm{s}, \Delta \mathrm{E}_{\mathrm{Q}}=0.88 \mathrm{~mm} / \mathrm{s}\right)$ of the spectrum of the intermediate. They are plotted at $46 \%, 23 \%, 12 \%, 40 \%, 22 \%$, and $14 \%$ of the total intensity of spectra $\mathbf{A}$ through $\mathbf{F}$, respectively. 


\section{Price et al, Scheme S1}

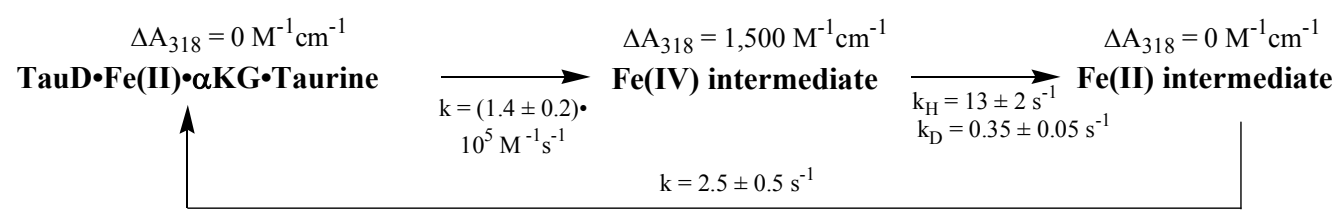


A

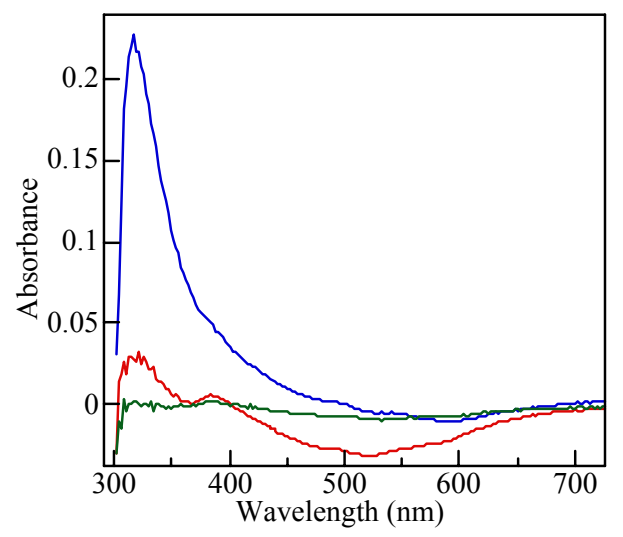

B

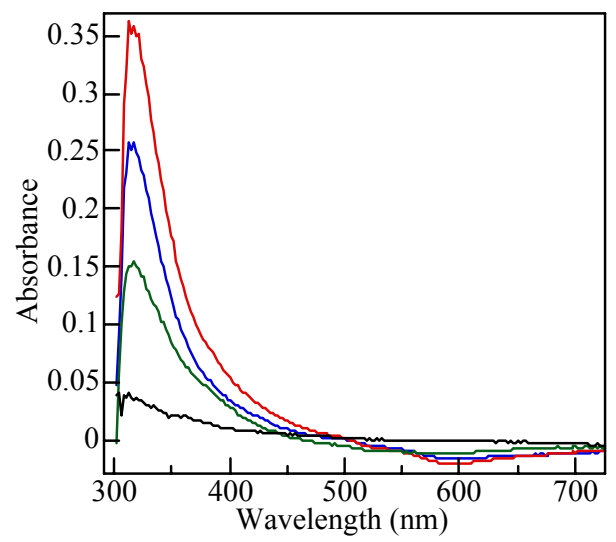

\section{Price, et al. Figure S1}




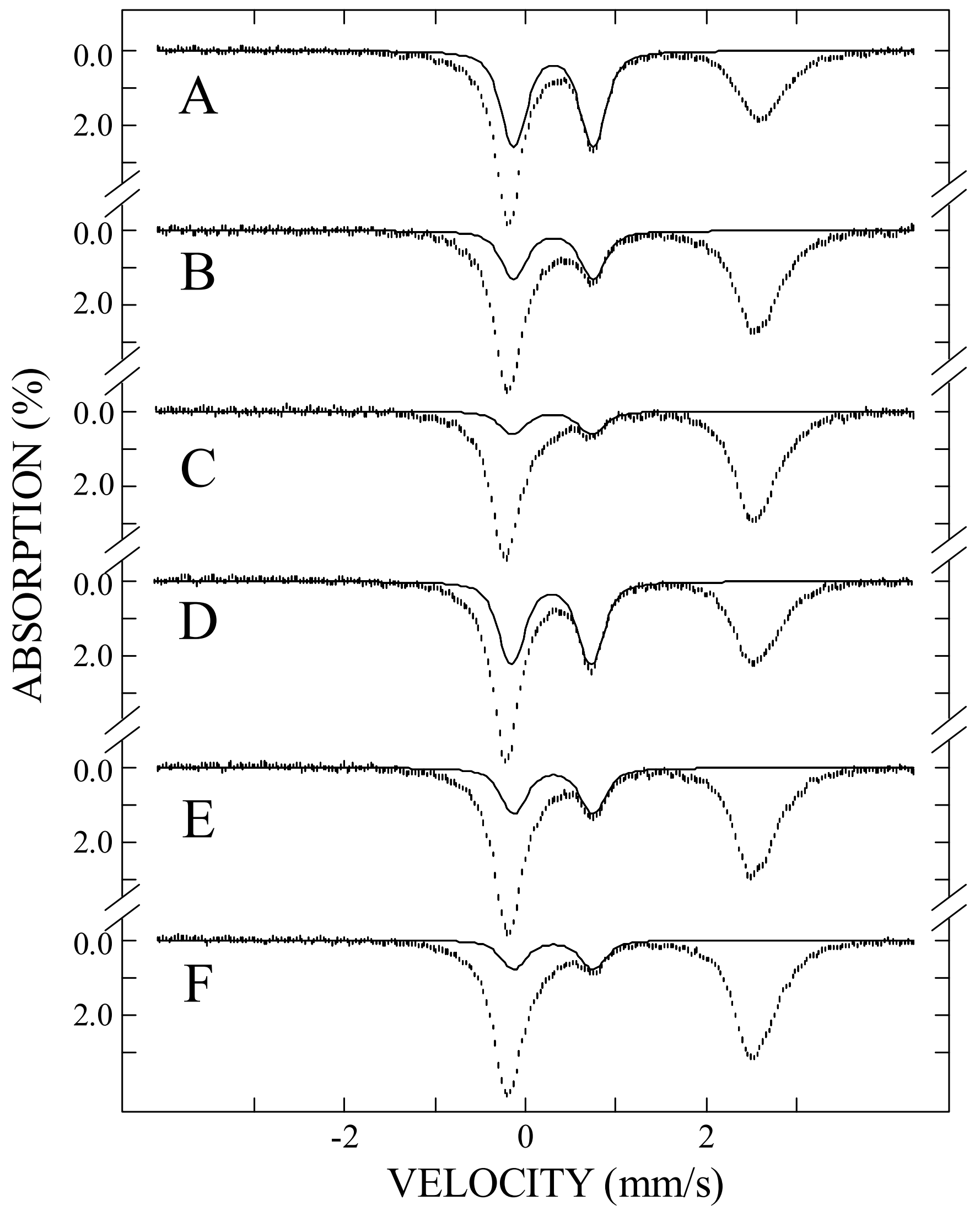

Price, et al. Figure S2 